\title{
Evidence of Helicobacter sp. in Dental Plaque of Captive Dolphins (Tursiops gephyreus)
}

Cinthia G. Goldman, ${ }^{1,6}$ Julio D. Loureiro, ${ }^{2,3}$ Viviana Quse, ${ }^{2,3}$ Daniel Corach, ${ }^{4}$ Enrique Calderon, ${ }^{2}$ Ricardo A. Caro, ${ }^{1}$ José Boccio, ${ }^{1}$ Sergio Rodríguez Heredia, ${ }^{2}$ Maria B. Di Carlo, ${ }^{5}$ and Marcela B. Zubillaga ${ }^{11}$ Radioisotope Laboratory, School of Pharmacy and Biochemistry, University of Buenos Aires, Buenos Aires, Argentina; ${ }^{2}$ Mundo Marino Foundation, San Clemente del Tuyú, Argentina; ${ }^{3}$ Mundo Marino Oceanarium, San Clemente del Tuyú, Argentina; ${ }^{4}$ DNA Fingerprint Gene Service and Genetics and Molecular Biology Department, School of Pharmacy and Biochemistry, University of Buenos Aires, Buenos Aires, Argentina; ${ }^{5}$ Clinical Biochemistry Department, School of Pharmacy and Biochemistry, University of Buenos Aires, Buenos Aires, Argentina; ${ }^{6}$ Corresponding author (email: cgold@ffyb.uba.ar)

ABSTRACT: Gastrointestinal lesions have been extensively reported in wild and captive marine mammals. However, their etiology remains unclear. In humans and other animals, chronic gastritis and peptic ulcers have been associated with Helicobacter sp. Therefore, the aim of our study was to investigate the presence of Helicobacter sp. in the gastric juice, dental plaque, and saliva of marine mammals living in a controlled environment. Five dolphins (Tursiops gephyreus), one killer whale (Orcinus orca), one false killer whale (Pseudorca crassidens), three sea lions (Otaria flavescens), two elephant seals (Mirounga leonina), and two fur seals (Arctocephalus australis) were studied. Saliva, dental plaque, and gastric juice samples were examined for Helicobacter sp. using polymerase chain reaction. None of the gastric juice or saliva samples were positive for Helicobacter sp. However, Helicobacter sp. DNA was detected in dental plaque from two dolphins, suggesting the oral cavity might be a reservoir of this bacterium.

Key words: Dental plaque, dolphins, gastritis, Helicobacter, marine mammals, oral cavity.

Discovery of Helicobacter pylori in human gastric biopsies represented a revolution in understanding gastroduodenal disease (Marshall and Warren, 1984) and demonstrated that most of these conditions are infectious diseases. Helicobacter pylori, a Gram negative, microaerophilic bacterium, is involved in the development of gastroduodenal lesions and is strongly associated with gastric adenocarcinoma in humans (Blaser, 1996; Dunn et al., 1997). Helicobacter pylori and other Helicobacter spp. also occur in gastrointestinal lesions in animals (Fox and Lee, 1997; Neiger et al., 1998). Isolation of $H$. pylori from feline gastric fluid, saliva, and feces suggest- ed that transmission of the infection to humans might occur (Fox et al., 1996).

Gastritis and peptic ulcers have been reported in wild dolphins and in marine mammals living in controlled environments. In the southwest Atlantic Ocean, digestive tract disease was reported in $20 \%$ of the species of wild marine mammals examined (Loureiro et al., 1996a), however, the etiology of those lesions was unclear. Stress, parasitic infections, consumption of foreign objects, and/or high concentrations of dietary histamine intake have been suggested as causes (Sweeney and Ridgway, 1975). Recent isolation of Helicobacter sp. from gastric mucosa of dead dolphins suggests an infectious etiology for gastric ulcers in marine mammals (Harper et al., 2000). The aim of our study was to investigate the presence of Helicobacter sp. in the gastric juice, saliva, and dental plaque of captive marine mammals with and without clinical signs compatible with gastritis.

Thirteen marine mammals living in the Mundo Marino Oceanarium (San Clemente del Tuyú, Argentina; $36^{\circ} 18^{\prime} \mathrm{S}, 56^{\circ} 46^{\prime} \mathrm{W}$ ) and one living in the Rehabilitation Centre of Mundo Marino Foundation (San Clemente del Tuyú, Argentina) were studied for the presence of Helicobacter sp. (Table 1). All animals except an elephant seal (Mirounga leonina) from the Rehabilitation Centre, had been trained for collection of medical samples. Animals at the Oceanarium were clinically examined for 1 yr prior to the start of this study. Clinical evaluation consisted of detailed observations of behavior and periodic examination 
TABLE 1. Marine mammals studied and results of PCR on samples from the stomach and oral cavity.

\begin{tabular}{|c|c|c|c|c|c|c|c|}
\hline Species & $\begin{array}{l}\text { Age } \\
(\mathrm{yr})\end{array}$ & Sex ${ }^{\mathrm{a}}$ & $\begin{array}{l}\text { Weight } \\
(\mathrm{kg})\end{array}$ & $\begin{array}{l}\text { Length } \\
(\mathrm{m})\end{array}$ & Gastritis $^{\mathrm{b}}$ & Sample ${ }^{c}$ & $\begin{array}{l}\text { PCR } \\
\text { results } \\
(\mathrm{DP})\end{array}$ \\
\hline \multirow{5}{*}{$\begin{array}{l}\text { Dolphin } \\
\quad \text { (Tursiops gephyreus) }\end{array}$} & 15 & $\mathrm{~F}$ & 296 & 3.07 & - & GJ, S, DP & - \\
\hline & 19 & $\mathrm{~F}$ & 312 & 3.10 & - & GJ, S, DP & - \\
\hline & 5 & M & 306 & 2.80 & + & GJ, S, DP & + \\
\hline & 18 & $\mathrm{~F}$ & 314 & 3.11 & + & GJ, S, DP & + \\
\hline & 19 & M & 420 & 3.20 & - & GJ, S, DP & - \\
\hline $\begin{array}{l}\text { Killer whale } \\
\text { (Orcinus orca) }\end{array}$ & 11 & M & 2,300 & 5.30 & - & GJ, S, DP & - \\
\hline $\begin{array}{l}\text { False killer whale } \\
\text { (Pseudorca crassidens) }\end{array}$ & 1 & M & ND & 2.73 & - & GJ, $\mathrm{S}$ & $\mathrm{ND}^{\mathrm{e}}$ \\
\hline Sea lion & 8 & $\mathrm{~F}$ & 97 & 1.70 & - & $\mathrm{S}$ & ND \\
\hline \multirow[t]{2}{*}{ (Otaria flavescens) } & 23 & $\mathrm{~F}$ & 120 & 1.78 & - & GJ, S, DP & - \\
\hline & 15 & $\mathrm{~F}$ & 104 & 1.80 & - & GJ, S & ND \\
\hline \multirow{2}{*}{$\begin{array}{l}\text { Fur seal } \\
\quad \text { (Arctocephalus australis }\end{array}$} & 17 & M & 84 & 1.62 & - & GJ, S, DP & - \\
\hline & 11 & $\mathrm{~F}$ & 43 & 121 & - & GJ, S, DP & - \\
\hline \multirow{2}{*}{$\begin{array}{l}\text { Elephant seal } \\
\quad \text { (Mirounga leonina) }\end{array}$} & 17 & M & ND & 3.71 & - & GJ, S, DP & - \\
\hline & 0.25 & M & 50 & 1.30 & - & $\mathrm{GJ}, \mathrm{S}$ & ND \\
\hline
\end{tabular}

${ }^{\mathrm{a}} \mathrm{F}=$ female, $\mathrm{M}=$ male.

${ }^{\mathrm{b}}$ Clinical evidence of gastritis present $(+)$ or not present $(-)$.

${ }^{\mathrm{c}} \mathrm{GJ}=$ gastric juice, $\mathrm{S}=$ saliva, $\mathrm{DP}=$ dental plaque.

$\mathrm{d}$ Negative for all gastric juice and saliva samples.

e $\mathrm{ND}=$ not determined.

of gastric contents to determine if clinical signs could be related to gastric disease (Table 1). Gastritis in cetaceans is characterized by inappetence, lack of interaction with other mammals and trainers, anorexia, abdominal tenderness, depression, and occasional unresponsiveness (Sweeney and Ridgway, 1975). In pinnipeds, the signs of gastroduodenal inflammation include chronic variability in food intake, depression, reduction in activity, tucked-up body posture while in water and on land, and reluctance to enter water (Sweeney, 1990).

Cetaceans were fasted for 14-16 hr and pinnipeds for 8-14 hr before samples were taken. Saliva was collected from the oral cavity using sterile plastic pipettes and by swabbing buccal mucosal surfaces with sterile cotton applicators. Dental plaque samples were removed from the tooth surfaces with a sterile periodontal curette. Gastric juice was aspirated from the stomach by gastric intubation.

Samples were processed within $1 \mathrm{hr}$ after being collected. An aliquot of gastric juice was separated for physicochemical, macroscopic, and microscopic examination. Gastric juice samples were then filtered and immediately buffered to neutral $\mathrm{pH}$ with an equal volume of Tris/ $\mathrm{HCl}(0.67$ $\mathrm{M}, \mathrm{pH}$ 7.4). Each neutralized gastric juice sample was concentrated by centrifugation at $11,000 \times \mathrm{G}$ and supernatants removed. Gastric juice pellets, saliva, and dental plaques received $0.5 \mathrm{ml}$ of extraction buffer $(10 \mathrm{mM}$ Tris $\mathrm{HCl}[\mathrm{pH} 7.4], 10 \mathrm{mM}$ EDTA, $100 \mathrm{mM} \mathrm{NaCl}, 2 \%$ sodium lauryl sulphate) containing proteinase $\mathrm{K}$ (final concentration $100 \mu \mathrm{g} / \mathrm{ml}$ ), and the mixtures were incubated at $55 \mathrm{C}$ overnight. For DNA extraction, an equal volume of phenol saturated in Tris $\mathrm{HCl}$ and stabilized with $\alpha$-hydroxyquinaline was added and the samples were centrifuged at $3,500 \times \mathrm{G}$ for $10 \mathrm{~min}$. The upper aqueous layer was recovered, and an equal volume of chloroform:isoamyl alcohol $(24: 1 ; \mathrm{vol} / \mathrm{vol})$ was added. The samples were centrifuged at $3,500 \times \mathrm{G}$ for an additional $10 \mathrm{~min}$. To concentrate DNA, the upper aqueous layer was transferred into the sample reservoir of a Microcon ${ }^{\circledR}-100$ (Amicon, Millipore 
Corp., Bedford, Maryland, USA), following manufacturer's instructions.

Polymerase chain reaction (PCR) was carried out with two primers, EHC-U and EHC-L (Li et al., 1995), which amplified a 417 base pair fragment from 860-bp DNA of $H$. pylori. Its sequences (expressed $5^{\prime}$ to $3^{\prime}$ ) were as follows: EHC-U (CCCTCACGCCATCAGTCCCAAAAA) and EHC-L (AAGAAGTCAAAAACGCCCCAAAAC). Amplification was carried out in a total volume of $30 \mu \mathrm{l}$ containing PCR buffer $(50 \mathrm{mM} \mathrm{KCl}, 10 \mathrm{mM}$ Tris $\mathrm{HCl}$ [pH 9.0 at $25 \mathrm{C}$ ] and $0.1 \%$ Triton ${ }^{\circledR}{ }_{-} \mathrm{X} 100$ ), $1.5 \mathrm{mM} \mathrm{MgCl} 2,200 \mu \mathrm{M}$ (each) deoxynucleotides, $0.75 \mathrm{U}$ of Taq polymerase (Promega Corp., Madison, Wisconsin, USA), $0.5 \mu \mathrm{M}$ each oligonucleotide primer, and $10 \mu \mathrm{l}$ of DNA template. Thirty cycles of amplification were performed with an automatic thermal cycler (PCR 9600 System, Applied Biosystems, Foster City, California, USA). Each cycle consisted of a $45 \mathrm{sec}$ denaturation step at $94 \mathrm{C}$, a $30 \mathrm{sec}$ annealing step at $59 \mathrm{C}$, and a $45 \mathrm{sec}$ extension step at $72 \mathrm{C}$. The final cycle included extension for $10 \mathrm{~min}$ at $72 \mathrm{C}$ to ensure full extension of the product. The completed reactions were analyzed by electrophoresis of a $10 \mu \mathrm{l}$ aliquot through $1.5 \%$ (wt/vol) agarose gel stained with ethidium bromide, and the bands were visualized by excitation under UV light. Purified DNA from H. pylori (ATCC 43504D) was employed as a positive control and it was amplified as described above. As a negative control, a reaction mixture containing distilled water in place of the DNA sample was included with each batch.

Color and $\mathrm{pH}$ of gastric juice samples were in the normal range for each species (Loureiro et al., 1996b). The gastric juice samples were negative for parasites, and no evidence of inflammation or hemorrhage was observed by microscopic examination.

Gastric juice and saliva samples were negative for Helicobacter sp. DNA by PCR analysis. However, by PCR amplification two $(20 \%)$ of 10 dental plaque samples

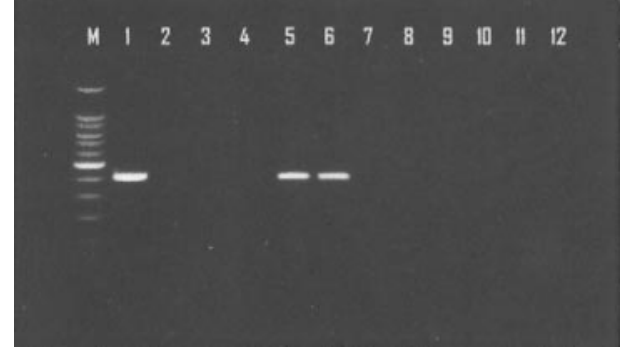

FIGURE 1. Polymerase chain reaction products from dental plaque samples from marine mammals using the primers EHC-U and EHC-L. Lane M: 100bp ladder, lane 1: Helicobacter pylori (ATCC 43504D) positive control, lane 2: negative control, lanes 3-12: dental plaque samples from marine mammals examined in this study, lanes 5-6 from dolphins (Tursiops gephyreus).

were positive for Helicobacter sp. DNA (Fig. 1; Table 1).

The primers EHC-U and EHC-L we used are considered highly specific for identification of H. pylori ( $\mathrm{Li}$ et al., 1993, 1995; Song et al., 1999). Nevertheless, their specificity for $H$. pylori in animal species which may carry novel Helicobacter spp. closely related to $H$. pylori has not yet been determined. For this reason, further research should be performed to confirm the species of Helicobacter found in the dental plaque of dolphins.

The positive PCR results from dental plaque were obtained from dolphins with clinical signs compatible with gastritis during the year before this study was conducted. These dolphins were receiving an antacid treatment. Negative results from the gastric juices are not surprising; antacids may inhibit Helicobacter spp. growth and PCR (Wadowsky et al., 1994; Nakao and Malfertheiner, 1998).

The mode of transmission of $H$. pylori infection among humans remains unclear. Due to the fact that $H$. pylori has been isolated from human saliva, dental plaque, and feces, oral-oral and fecal-oral transmission have been suggested ( $\mathrm{Li}$ et al., 1996; Oshowo et al., 1998; Song et al., 1999). The oral cavity may be a reservoir of this bacterium (Thomas et al., 1997). However, other authors maintain that $H$. 
pylori is present in the oral cavity due to regurgitation of contaminated gastric juice (Madinier et al., 1997). Our finding of $\mathrm{Hel}$ icobacter sp. in dental plaque samples of dolphins suggests that an oral location of this bacterium might occur in species other than humans.

To our knowledge, this is the first report of Helicobacter sp. in the dental plaque of dolphins. More research is required to understand the role of Helicobacter sp. in gastrointestinal diseases in marine mammals and to clarify its role in the oral cavity.

We thank the team of Mundo Marino Foundation, the trainers, and R. Lafuente for their kind collaboration.

\section{LITERATURE CITED}

Blaser, M. 1996. The bacteria behind the ulcers. Scientific American 274: 92-97.

Dunn, B. E., H. Cohen, and M. J. Blaser. 1997. Helicobacter pylori. Clinical Microbiology Reviews 10: 720-741.

Fox, J. G., AND A. LEE. 1997. The role of Helicobacter species in newly recognized gastrointestinal tract diseases of animals. Laboratory Animal Science 47: 222-255.

- S. Perkins, L. Yan, Z. Shen, L. Attardo, AND J. PAPPO. 1996. Local immune response in Helicobacter pylori-infected cats and identification of $H$. pylori in saliva, gastric fluid and faeces. Immunology 88: 400-406.

Harper, C. M. G., C. A. Dangler, S. Xu, Y. Feng, Z. Shen, B. Sheppard, A. Stamper, F. E. DeWhirst, B. J. PAster, AND J. G. Fox. 2000. Isolation and characterization of a Helicobacter sp. from the gastric mucosa of dolphins, Lagenorhynchus acutus and Delphinus delphis. Applied Environmental Microbiology 66: 4751-4757.

Li, C., D. A. Ferguson JR., T. Ha, D. S. Chi, and E. Thomas. 1993. A highly specific and sensitive DNA probe derived from chromosomal DNA of Helicobacter pylori is useful for typing H. pylori isolates. Journal of Clinical Microbiology 31: 2157-2162.

- P. R. Musich, T. Ha, D. A. Ferguson JR., N. R. Patel, D. S. Chi, and E. Thomas. 1995. High prevalence of Helicobacter pylori in saliva demonstrated by a novel PCR assay. Journal of Clinical Pathology 48: 662-666.

, T. Ha, D. A. Ferguson, D. S. Chi, R. Zhao, N. R. Patel, G. Krishnaswamy, and E. ThomAS. 1996. A newly developed PCR assay of $H$. pylori in gastric biopsy, saliva, and feces. Evidence of high prevalence of $H$. pylori in saliva supports oral transmission. Digestive Diseases and Sciences 41: 2,142-2,149.

Loureiro, J. D., R. Bastida, V. Quse, F. Costa, D. RODRIGUEZ, AND V. RUOPPOLO. 1996a. Rehabilitación y reintroducción de mamíferos marinos a través de la Fundación Mundo Marino (San Clemente del Tuyú, Argentina). Proceedings of the VII Reunión de Trabajo de Especialistas en Mamíferos Acuáticos de América del Sur y I Congreso de la Sociedad Latinoamericana de Especialistas en Mamíferos Marinos (SOLAMAC), p. 108.

, V. Quse, AND A. Mosca. 1996b. Descripción de las principales enfermedades en mamíferos marinos en el Centro de Rehabilitación de la Fundación Mundo Marino (San Clemente del Tuyú, Argentina). Proceedings of the VII Reunión de Trabajo de Especialistas en Mamíferos Acuáticos de América del Sur y I Congreso de la Sociedad Latinoamericana de Especialistas en Mamíferos Marinos (SOLAMAC), p. 108.

Madinier, I. M., T. M. Fosse, And R. A. Monteil. 1997. Oral carriage of Helicobacter pylori: A review. Journal of Periodontology 68: 2-6.

MarshalL, B. J., AND J. R. WARREN. 1984. Unidentified curved bacilli in the stomach of patients with gastritis and peptic ulceration. Lancet i: 1311-1314.

NakaO, M., And P. Malfertheiner. 1998. Growth inhibitory and bactericidal activities of Lansoprazole compared with those of Omeprazole and Pantoprazole against Helicobacter pylori. Helicobacter 3: 21-27.

Neiger, R., C. Dieterich, A. Burnens, A. WaldVOGEL, I. CORThesy-Theulaz, F. Halter, B Lauterburg, and A. Schmassmann. 1998. Detection and prevalence of Helicobacter infection in pet cats. Journal of Clinical Microbiology 36: 634-637.

Oshowo, A., D. Gilliam, A. Botha, M. Tunio, J. Holton, P. Boulos, AND M. Hobsley. 1998. Helicobacter pylori: The mouth, stomach, and gut axis. Annals of Periodontology 3: 276-280.

Song, Q., B. Haller, R. M. Schmid, G. Adler, AND G. BODE. 1999. Helicobacter pylori in dental plaque. A comparison of different PCR primer sets. Digestive Diseases and Sciences 44: 479484.

Sweeney, J. 1990. Marine mammal behavioral diagnostics. In Handbook of marine mammal medicine: Health, disease, and rehabilitation, L. A. Dierauf (ed.). CRC Press, Boca Raton, Florida, pp. 53-72.

- AND S. H. RidgWaY. 1975. Common diseases of small cetaceans. Journal of the American Veterinary Medical Association 167: 533-540.

Thomas, E., C. Jiang, D. S. Chi, C. LI, AND D. A FERGUSON. 1997. The role of the oral cavity in Helicobacter pylori infection. The American Journal of Gastroenterology 92: 2148-2154. 
Wadowsky, R. M., S. Laus, T. Libert, S. J. States, AND G. D. EHRLICH. 1994. Inhibition of PCRbased assay for Bordetella pertussis by using calcium alginate fiber and aluminum shaft compo- nents of a nasopharyngeal swab. Journal of Clinical Microbiology 32: 1054-1057.

Received for publication 7 March 2001. 